\title{
Physics Programs in Secondary Education from the Establishment of the Republic of Turkey to Present Day
}

\author{
Ayşe Gül (Çirkinoğlu) Şekercioğlu ${ }^{1, *}$ \\ ${ }^{1}$ Necatibey Education Faculty, Balıkesir University, 10100, Balıkesir, Turkey \\ *Correspondence: Necatibey Education Faculty, Balıesir University, 10100, Balıkesir, Turkey. E-mail: \\ acirkin@balikesir.edu.tr
}

Received: May 18, 2018

Accepted: June 12, 2018 Online Published: October 1, 2018

doi:10.5430/jct.v7n2p78

URL: https://doi.org/10.5430/jct.v7n2p78

\begin{abstract}
'Program development' is a systematic process which includes steps such as determining general and specific goals of teaching, choosing appropriate program materials, determining teaching methods, evaluation and assessment tools, designing formal outlines for every lesson, testing and finalizing the program, continual monitoring, evaluating program, and lastly enhancing program. This study examines contents of Physics lessons in Turkey and what kind of changes has been made to the program throughout years. It also gives information concerning historical development of this process since1924, in which the law of Tevhid-i Tedrisad was passed, to present day. Any new program is initially practiced at pilot schools and then extended to other schools in the country, which seems in accordance with the principles of the program development process. However, these programs have been practiced for only one or two years at pilot schools, then directly extended to local schools throughout the country without making any necessary improvements or enhancements to the program. This practice, as the study findings suggest, creates a vicious cycle. When deficiencies in past programs became obvious even at other schools, the authorities immediately attempted to develop a completely new program, which was again applied and abolished using same procedures. This is a prime reason for why goals for education cannot be short-term. Additionally, study findings showed that experts who design Physics programs in Turkey do not complete detailed unit analysis of Physics lessons, which in turn causes Physics teachers at schools to face problems when planning effective lessons and setting goals for class.
\end{abstract}

Keywords: physics lesson, physics program, high school, Republic of Turkey

\section{Introduction}

A program is a design which includes certain parts, and the implementation order, time and method of these parts in a specific task. Program concept in education is used in various forms such as education programs, teaching programs, school programs, curriculum programs and course programs etc. (Büyükkaragöz and Çivi, 1998).

The concept of program development is defined as "the systematic program development process for a specific school or school system" in educational terms. It is prepared by experts under specific rules. It includes that stages of determining the general and specific goals, choosing the appropriate materials, determining the assessment instruments, composing a formal program draft for each course, implementing the draft, finalizing the program, continual monitoring, analyzing and evaluation of the designed program and the improvements processes. To Demirel (2004), program development includes all dynamic relations among goal, content, education and assessment components within education programs.

For Büyükkaragöz and Çivi (1998), program development aims either to improve an already existing program to be more concrete, stable and effective or to design a completely new program to be concrete, stable and effective. In other words, program development contains all coordinated efforts to improve activities to realize and improve the goals of both National Education and schools effectively through making use of correct methods, techniques, instrument and tools (Varış, 1976).

According to Ertürk (1984), the first step in program development is the determination of the goals. Goals are the basic sources to use in determining the behaviors; behaviors are the basic sources to use in determining learning experiences; behaviors and learning experiences are the basic sources to use in determining the assessment process. There is an 
interrelated relationship among the program components, and the assessment data should be used to analyze all components, and thus to improve the program. Ertürk who acknowledged philosophy as an inevitable source of program development, indicated that philosophy can be utilized to add novel goals to the old ones, to organize the goals through analyzing their internal and external consistencies, to order the goals in terms of importance and to survey the social environment, topic of field and individuals.

After the declaration of the Republic of Turkey, as in every field in Turkey, innovations began to take place in the National Education System. One of these innovations was changing the names of schools: in 1923 the $1^{\text {st }}$ Council of Education and Religious Affairs (Heyet-i İlmiye) the name of secondary education institutions sultani was transformed into high school. During the 1923-1924 education year, there were a total of 1,240 students, 330 of whom were at 9 girls' high school and 910 of whom were at 14 boys' high school (Cicioğlu, 1985).

The secondary education teaching program had undergone various changes since the Ottoman period, and during the war of independence, the Ankara government tried to change the program twice. During the management of Deputy of Education Mehmet Vehbi, sultani schools were attempted to be named "new madrasa" (Muslim theological school) and a new teaching program was prepared in which there were traces of eastern culture. However, this program was never put into practice. Again in 1922, a second program was prepared and never applied again. This program claimed to establish all schools in accordance with a sample school. In this sense, all institutions which were separate from each other in terms of class, course and management would be abolished, and integrated under one institution, which shows that the integration of education would be integrated was partially achieved. In the second program, surveys were delivered to teachers of that time and their opinions were gathered, yet the practice of this program was never been achieved. Then, these surveys which show the general opinions about the Law on Unification of Education in 1922, were published as a whole (Türkoğlu, 1984).

The aim of the study is examine secondary education Physics programs historically in terms of course hour and content variables and since the Proclamation of the Republic to today. Physics is of crucial importance in terms of keeping up with today's technology and developing the country scientifically. Thus, it is a must to analyze, compare and detect the missing parts in Physics programs.

\section{Method}

The study data was collected by means of document analysis. The document analysis method covers the process of collecting data through analyzing documents including information about concepts and events related to a specific topic. For document analysis, all issues of the National Education Ministry, Notices Journals since 1928 to today were analyzed and it was supported with the data from related articles and books. The data was analyzed via descriptive analysis, which aims to present the obtained data after organization and interpretation processes, and in which the data is summarized and classified under previously determined themes (Yıldırım, Şimşek, 2003).

\section{Results}

After the proclamation of the Republic in 1923, the most prominent events related to the studies on secondary education teaching programs were the separation of science and literature classes in the second grade at high schools and the foundation of second grade high schools in 1924. The separation of science and literature classes was applied at the third class of the second grade at high schools (Türkoğlu, 1984).

One of the decisions made by the $2^{\text {nd }}$ Council of Education and Religious Affairs (Heyet-i Ilmiye) was to describe the durations of primary and secondary education institutions in accordance with the conditions at that time. In this sense, decisions such that high schools were decreased from 4 years to 3 years, that the separation in branches of science and literature was done at the last class of high school, that the circuited high schools were transformed into secondary schools, that girls' high schools were transformed to match boys' high schools, that changes were made to the education programs of secondary schools, high schools and teacher training high schools, that sociology courses were included in the program and that the course books would be published were made. The teaching programs of primary, secondary and high schools were changed. It was acknowledged to apply a five-year primary education, then a three-year secondary education and then again a three-year high school education. This program was applied for three years, and then considering the supervisors' reports and teachers' opinions, the contents of literature, history, geography and mathematics courses were changed (Cicioğlu, 1985).

It was revealed that in 1924, the Physics course was two hours at $1^{\text {st }}$ and $2^{\text {nd }}$ class at high school, and at the $3^{\text {rd }}$ class, the students chose one of the branches called Science and Literature. The students choosing Science received two hours of 
Physics weekly. No sources were found concerning the 1924 high school program contents. The 1924 high school program was applied for three years and then changes were made in the programs of literature, history, geography and mathematics. In 1927, the Science and Mathematics program of $1^{\text {st }}$ and $2^{\text {nd }}$ class of high school was changed before students chose between the branches of science and literature. The science content was decreased in literature branch while the courses related to science were increased in science (e.g. Physics, chemistry, plant and animal physiology etc.). In the $1^{\text {st }}$ and $2^{\text {nd }}$ classes of high school, the physics was 2 hours while in the $3^{\text {rd }}$ class at science branch 2 hours and 1 hour at $3^{\text {rd }}$ class literature branch.

In 1931, some of the courses in the high school program was unified under one course. Hence, the courses "Plant and Animal Physiology" and "arziyat" were unified under the name of "tabiye"; "müsellat", "cebir", "hendese", "nazari hesap", "mihanik" and "cosmography" were unified under "riyaziye." In this program, no changes were seen in Physics. Only at $1^{\text {st }}$ class of high school, it was increased to 3 hours weekly while it was same with 1927 program at other class levels. This program was implemented until 1934. In the 1934 program, no considerable changes were made, and it was aimed to integrate all previous programs under one program. Only at the $1^{\text {st }}$ class high school, the physics course was decreased to two hours weekly (Türkoğlu, 1984; Cicioğlu, 1985).

In 1935, separate program guidelines were prepared for each course. To these guidelines, the subjects that were thought to be too high for students' levels such as electrostatics, capillarity were excluded from the program, and doing more experiments was emphasized. These guidelines were applied in the 1935-1936 education year, and then in 1937, there some changes made in mathematics, physics and chemistry courses. Through adding a laboratory course to the program, the number of Physics course hours was increased, and experimental studies were focused (Türkoğlu, 1984).

Table 1. Weekly Physics Course Hours Between 1924-1949

\begin{tabular}{llllll}
\hline \multirow{2}{*}{ Year } & \multirow{2}{*}{ Course } & 1.Class & \multirow{2}{*}{ 2.Class } & \multicolumn{2}{l}{ 3.Class } \\
\cline { 5 - 6 } & & & Science & Literature \\
\hline 1924 & Physics & 2 & 2 & 2 & - \\
1927 & Physics & 2 & 2 & 2 & 1 \\
1931 & Physics & 3 & 2 & 2 & 1 \\
1934 & Physics & 2 & 2 & 2 & 1 \\
& Physics & 2 & 2 & 2 & 1 \\
1937 & Physics Lab. & 1 & 1 & 1 & $1 / 2$ \\
& Mathematics & 5 & 4 & 8 & 2 \\
1947 & Physics & 3 & 3 & 3 & 1.5 \\
1949 & Physics & 3 & 3 & 3 & 1.5 \\
\hline
\end{tabular}

Within the 8-hour mathematics course at $3^{\text {rd }}$ class at high school consisted of two hours of algebra, one hour müsellat, one hour of mechanic and one hour of cosmography. Since the mechanic topic here was one of the physics course, the number of physics course rose indirectly. In 1936, most of the committee members in "Program Modification Commission" charged by National Education Ministry with the aim to make modifications on the program, were German, thus the program and books were prepared on the basis of German books and system. These textbooks began to be taught in the 1937-1938 education year, and physical sciences and biology courses were removed and again animals, plants, physics and chemistry courses were replaced (Cicioğlu, 1985).

In the 1937 program, there were some changes made to course hours, and it was published as 1938-revised program. In this renewed program, only "natural sciences" course was renamed "knowledge on nature." Apart from this, no crucial changes were made to the program. 1938 program was applied until 1947 although it had undergone a few changes. In 1947, at some high schools, a new branch called "Latin" was opened. There were not made any changes in Physics program. The total course hour of physics was the same as in 1937 program. At the $1^{\text {st }}$ and $2^{\text {nd }}$ classes, the physics course was 3 hours; at $3^{\text {rd }}$ class of science branch, it was 3 hours again, and 1.5 hours at $3^{\text {rd }}$ class literature branch (NEM, 1947).

In a commission held in 1949, it was asserted that the program of secondary grade schools were not sufficient and functional. The commission decided to increase high schools up to four years, to make use of methods and techniques which could help young people improve their skills and to decrease classroom size to 35-40 students. However, some these decisions were not put into practice (Ünal \& Ünal, 2010). Also, the "Latin" class which was integrated into the program in 1947, was abolished. And, at the $1^{\text {st }}$ and $2^{\text {nd }}$ classes, the physics course was 3 hours; at $3^{\text {rd }}$ class of science branch, it was 3 hours again, and 1.5 hours at $3^{\text {rd }}$ class literature branch (NEM, 1949). In 1949, the high schools were 
increased to four years, and it was implemented till 1952. In this four-year high school program which was applied between 1952 and 1955, the separations to branches were at the fourth class (NEM, 1949; Cicioğlu, 1985).

Table 2. Weekly Physics Course Hours at High School Program in 1952

\begin{tabular}{llllll}
\hline Course & 1.class & 2.class & 3.class & \multicolumn{2}{l}{ 4.class } \\
\cline { 3 - 6 } & & & & Science & Literature \\
\hline Physics & - & 3 & 3 & 3 & 1 \\
\hline
\end{tabular}

With a new program designed in 1956, the high schools were decreased to three years. Thus, the separation to science and literature branches were started to be done at $3^{\text {rd }}$ class again.

Table 3. Weekly Physics Course Hours at High School Program in 1956

\begin{tabular}{lllll}
\hline Course & 1.class & 2.class & \multicolumn{3}{l}{ 3.class } & \\
\cline { 3 - 5 } & & & Science & Literature \\
\hline Physics & 3 & 3 & 3 & 2 \\
\hline
\end{tabular}

1956 program was applied only one year, and revised in 1957. An important change in the program was that the separation to branches was started to be implemented at the $2^{\text {nd }}$ class of high school. This situation of separation to branches at the $2^{\text {nd }}$ class, has continued same to even today (Cicioğlu, 1985, Arslanoğlu, 2001).

Table 4. Weekly Physics Course Hours at High School Program Between 1957-1970

\begin{tabular}{llllll}
\hline Course & 1.class & \multicolumn{2}{l}{ 2.class } & \multicolumn{2}{l}{ 3.class } \\
\cline { 3 - 6 } & & Science & Literature & Science & Literature \\
\hline Physics & 3 & 3 & 2 & 4 & 2 \\
\hline
\end{tabular}

In 1959, with the support of Organization for Economic Co-operation and Development (OECD) till 1965, the studies to improve modern mathematics and science programs were started. The aim of this project was to modernize secondary grade science education in a way to keep up with contemporary science and technique's needs. This modern mathematics and science program was started to be tried at 9 high schools in 1967-1968 education year. This program was based on placing specific concepts at each stage of basic science teaching process; on raising interest in positive sciences and scientific studies among students, and on ensuring students to catch the essence of scientific events (Türkoğlu, 1984).

In 1967, the Science Teaching Modification Commission was founded. The commission ensured that faculty members at universities dealt with secondary grade education problems with the most typical, comprehensive and successful way. After the establishment of the commission, BAYG-E 7 Project was came into force by National Education Ministry and TÜBİTAK (Scientific and Technological Research Council of Turkey) so as to popularize the program throughout all high schools in Turkey. In 1968, the agreement was renewed and the project was called BAYGE- 14. The science and mathematics programs used in the project was developed at science high schools. This program was known as Physical Science Study Committee which was founded in America in 1956, and was called as PSSC physics. Basically, is was a "topic program" it separated from the traditional programs in that it dealt with fewer topics but deeply, that it was depended on theoretical physics models, that it rarely gave space to technological practices of physics, and that it gave importance to understanding of general principles (Bozan, 2002).

After the modern science and mathematics program was attempted at 9 high schools, it began to be implemented at 100 high schools and 89 teacher training high schools. Also, in 1972, the Physics draft programs for second grade $2^{\text {nd }}$ classes for science branches, and the draft Science Education and Biology course programs for literature branches were accepted on the basis of the given class schedules (Arslanoğlu, 2001). 
Table 5. Science and Physics Course Topics in 1971 (NEM, 1973).

\begin{tabular}{|c|c|c|c|c|}
\hline $\begin{array}{l}\text { Science } \\
\text { Course }\end{array}$ & $\begin{array}{l}\text { Electric charge and Current } \\
\text { Matter and Electric Charge } \\
\text { Batteries and Charge Bearing } \\
\text { Heat Energy }\end{array}$ & $\begin{array}{l}\text { Heat Energy and Cur } \\
\text { Electric Energy and } \mathrm{H} \\
\text { Gravitational Potenti }\end{array}$ & $\begin{array}{l}\text { ent } \\
\text { eat Energy } \\
\text { Energy }\end{array}$ & $\begin{array}{l}\text { Potential Energy of Atoms } \\
\text { Kinetic Energy and other } \\
\text { energy sources } \\
\text { Conversation of Energy }\end{array}$ \\
\hline $\begin{array}{l}\text { Physics } \\
\text { Course }\end{array}$ & $\begin{array}{l}\text { General knowledge on } \\
\text { Physics } \\
\text { Light } \\
\text { Waves } \\
\text { Motion } \\
\text { Vectors } \\
\text { Newton's Law of Motion }\end{array}$ & $\begin{array}{l}\text { Motion on the Earth } \\
\text { Motion in the Space } \\
\text { Momentum } \\
\text { Kinetic Energy } \\
\text { Potential Energy } \\
\text { Heat }\end{array}$ & $\begin{array}{l}\text { Electric } \\
\text { Coulomb Law } \\
\text { Charges' Motions } \\
\text { in Electrical Field } \\
\text { Magnetic Field }\end{array}$ & $\begin{array}{l}\text { Electromagnetic Induction } \\
\text { and Electromagnetic Waves } \\
\text { Rutherford Atom } \\
\text { Photons } \\
\text { Atoms and Spectrums } \\
\text { Waves of Matter }\end{array}$ \\
\hline
\end{tabular}

According to the program which was put into practice in 1971, and to the draft Science Education program at Literature branch, for the students who wouldn't study science and who would continue to study social sciences, it was aimed to reinforce "Science Education I" program including Physics and Chemistry. In the "Science Education I" approach, the main theme was the structure of matter. In this program, the energy and energy status topics were accepted as basic topics. Thus, the integration of program was ensured through delivering both matter and energy topics and the relations between them in the successive classes. The suggested draft Science Education program for $2^{\text {nd }}$ class of high schools, namely for the student who would continue to study science and techniques, referred to that providing students with basic concepts for helping their following studies in addition to the methods given during "Science Education-I (Introduction to Physical Sciences)" (NEM, 1973).

After the 1971 physics program, a new program called Modern Science and Mathematics was developed, and began being applied at specific high schools in 1974. In preparing this program, the P.S.S.C. Physics program was used which composed the core method of Physic sciences as a result of following the traces of scientists for centuries, and enabled students to reach the most current scientific problems and present-day issues. Different from the previous program, in this program's literature branch, one lesson hour was decreased in mathematics, physics, history, geography, art history and national security courses, and two hours were excluded from chemistry course in literature branch. On the other side, for the science branch in the program, one hour was decreased in philosophy and national security courses; two hours were excluded from physics course, and three hours were excluded from chemistry course. Also, one hour ethics course was added to the curriculum of $9^{\text {th }}$ and $10^{\text {th }}$ classes.

The main characteristic of the program was that encouraging students to study individually, to examine the subjects closely and to teach how to think and assess scientifically about experiment results. In this sense, the idea of that through giving various example studies and comments to students about the agents who have contributed to science somehow, students can be made to adopt scientific thinking habit should be employed. The facilitative sources which were prepared in relation to the program included the laboratory books, new and basic experiment kits, movies, standard tests, teacher guidebooks and supportive books which were written by competent agents in the field (NEM, 1973).

Table 6. 1974- Physics Program's Weekly Course Hours (1974)

\begin{tabular}{lllllll}
\hline & Course & 1.class & \multicolumn{2}{l}{ 2.class } & \multicolumn{2}{l}{ 3.class } \\
\cline { 3 - 6 } & & & Science & Literature & Science & Literature \\
\hline $\begin{array}{l}\text { Trial High Schools applied } \\
\text { the Current Program }\end{array}$ & Physics & 3 & 3 & 2 & 4 & 2 \\
$\begin{array}{l}\text { Modern Science\&Math. Trial } \\
\text { High Schools }\end{array}$ & $\begin{array}{l}\text { Physics } \\
\text { Science Education }\end{array}$ & -4 & - & 4 & - & - \\
\hline
\end{tabular}

The training of teachers who had attended the in-service training courses held for popularizing the modern program throughout the whole high schools, slowed down since 1977 and ended soon. The discrimination of modern and classic at high schools continues during 1980s. Upon the withdrawal of Scientific and Technological Research Council of Turkey (TUBITAK) support from science projects, the studies to improve science education stopped acutely after 1980s. With the recommend of National Education Youth and Sports Ministry and with the Educational High 
Commission's decision in 1985, the discrimination of classic and modern at high schools was abolished. On 26 September in 1985, a new science program was accepted. This new program was started to be applied gradually beginning from the $1^{\text {st }}$ class of high school in 1985-1986 education year. During these years, with the book writing campaigns, one type of program was designed for physics, chemistry and biology courses. That the course books were prepared by a specific commission was a good indication for program development process. The physics course was included as 3 hours at $9^{\text {th }}$ classes; 4 hours at $10^{\text {th }}$ classes in science branch and 2 hours at $10^{\text {th }}$ classes in literature branch; 4 hours at $11^{\text {th }}$ classes in mathematic branch; 3 hours at $11^{\text {th }}$ classes in science branch and 2 hours at $11^{\text {th }}$ classes in literature branch (Bozan, 2002).

In the Notices Journal of 16 September, 1991, several decisions were made about Course Passing and Credit Regulations. Via these decisions, the schools, courses and weekly course hours were determined for applying the new regulations. The schools which would apply the new Course Passing and Credit Regulations were determined as government and private high schools which also delivered foreign language education, the Anatolian Fine Arts High School and Science High Schools. This program was improved, and accepted to be applied gradually starting from the 1991-1992 education year (NEM, 1991: 412). In the Notices Journal of 25 May, 1992, the decision called 128 "Course Passing Through Credit System Regulation" came into operation, and with the decision-173 made by the commission in 11 September, 1985, physics course programs for $1^{\text {st }}, 2^{\text {nd }}$ and $3^{\text {rd }}$ classes were abolished. The goals of the program were to teach students the basic concepts and laws which would facilitate them to use common physics applications better; to ensure students to gain the certain research abilities via making them to examine, observe and do experiment on physics events, to help them adopt a positive scientific view and perspective, to enable them to think over physics events in detail and comprehensively, to gain them the necessary knowledge and skills for their future studies at basic scientific branches, and to teach them how to learn them (NEM, 1992: 314).

Course Passing and Credit System was abolished in 1997 owing to several missing and a new physics program was started instead. In this program, the course passing on the basis of terms was modified. The aims of the new physic program were the same as Course Passing and Credit System and the content of the physics program was no changed although there were a few changes in other courses' program contents (NEM, 1996; NEM 1997).

The table beloved demonstrates the physics subjects in Credit System. Additionally, in the $2^{\text {nd }}$ class high school physics program of literature branch, there were the subjects of "Electrical Events", "Electric Current" and "Alternative Current".

Table 7. 1992-Credit System, The Distribution of Physics Subjects ((NEM, 1992: 314)

\begin{tabular}{llll}
\hline $1^{\text {st }}$ & Measuring and Unit Systems & Newton's Laws of Motion & Impulse and Momentum \\
class & Force Motion & Motion on the Earth & Energy \\
$2^{\text {nd }}$ & Magnetism & Electrical Current & Light \\
class & Electrostatic & Electromagnetic Induction & \\
$3^{\text {rd }}$ & Waves' Motion & Motions of Charges Particles in & Atomic Nucleus \\
class & Light Theories & Electric Fields & Solar Energy \\
& Atom Theories & & \\
\hline
\end{tabular}

With the decision published in Notices Journal-2573, 07.06.2006, "Reconstruction of Secondary Education" topic was discussed, and it was decided to increase education year of general, vocational and technical training high schools from three to four years gradually starting from $9^{\text {th }}$ class and 2005-2006 education year. Additionally, it was approved to increase the education year of high schools which had preparation language class; to determine course hours starting from primary grade to the end of secondary grade in accordance with European Union Foreign Language System; to give the public and private high schools of which education year was 5 years together with preparation class the alternative of maintaining their current system (NEM, 2005).

With this new decision, the total physic course hour in science branch was 10 hours. In social sciences, Turkish-mathematics and foreign language branches, it was 2 hours only at $9^{\text {th }}$ class. Also, 2 hours of physics course were delivered as an optional course. The weekly physics course hours were the same as general/public and Anatolian high schools. At 5-year Anatolian high schools which had preparation class, there was 1 hour of physics at preparation classes, which was different from other type of high schools. 
Table 8. 2005-2017 Weekly Physics Course Hours

\begin{tabular}{lllll}
\hline Year & 9.class & 10.class & 11.class & 12.class \\
\hline 2005 & 2 & 2 & 3 & 3 \\
2013 & 2 & 2 & 4 & 4 \\
2017 (Draft Prog.) & 2 & 2 & 4 & 4 \\
\hline
\end{tabular}

2007-Pyhsics program was different from the previous ones in that it was of a spiral structure including physics subjects at the every class of high school. The reason for such a radical change was the fact that at $9^{\text {th }}$ class level, all students had to receive physics course, but after the separation to branches, there were students who would never receive physics course again. By virtue of the change in $9^{\text {th }}$ class physics program, the whole students would be able to attain physics subjects although they would not receive physics course in the following class levels.

Table 9. 2007-Secondary Grade Physics Program Content

\begin{tabular}{|c|c|c|c|}
\hline 9. Class & $\begin{array}{l}\text { Waves } \\
\text { Nature of Physics and Energy }\end{array}$ & $\begin{array}{l}\text { Matter and Characteristics, } \\
\text { Force and Motion }\end{array}$ & Electric and Magnetism \\
\hline 10. Class & $\begin{array}{l}\text { Matter and Characteristics, } \\
\text { Force and Motion }\end{array}$ & $\begin{array}{l}\text { Electric } \\
\text { Modern Physics }\end{array}$ & Waves \\
\hline 11. Class & $\begin{array}{l}\text { Matter and Characteristics, } \\
\text { Force and Motion }\end{array}$ & $\begin{array}{l}\text { Magnetism } \\
\text { Modern Physics }\end{array}$ & $\begin{array}{l}\text { Waves } \\
\text { From Stars to Stellars }\end{array}$ \\
\hline 12. Class & $\begin{array}{l}\text { Matter and Characteristics, } \\
\text { Force and Motion, } \\
\text { Electric and Electronic }\end{array}$ & $\begin{array}{l}\text { Waves } \\
\text { Modern Physics }\end{array}$ & $\begin{array}{l}\text { From Atoms to Quarks } \\
\text { Nature of Physics }\end{array}$ \\
\hline
\end{tabular}

In this program, the subject were delivered to student as conceptual level as possible. This program was different from the previous physics programs in the past in that it adopted the in-class physics approach; that it associated physics subjects with real life situations and that the subject contents and related skills were presented to students in crosswise approach (NEM, 2007).

This program was started to be applied in 2007, and in 2013 there came a change in application of the program gradually. In this sense, the physics course hours were risen up to 4 hours weekly at $11^{\text {th }}$ and $12^{\text {th }}$ classes (NEM, 2013).

Table 10. 2013-Secondary Grade Physics Program Content (NEM, 2013)

\begin{tabular}{llll}
\hline \multirow{2}{*}{ 9. Class } & Introduction to Physics & Force and Motion Energy & Electrostatic \\
& Matter and Characteristics & Heat and Temperature & \\
10.Class & Pressure and Lifting Force & Electric and Magnetism & Waves Optic \\
11.Class & Force and Motion & Electric and Magnetism & \\
& Regular Circular Motions & Waves MechanicIntroduc. to Atom & Modern Physics \\
12.Class & Basic Harmonic Motions & Phys.\& Radioactivity & $\begin{array}{l}\text { Modern Phys. \&Tech. } \\
\text { Practices }\end{array}$ \\
\hline
\end{tabular}

In January of 2017, the modification of the program was mentioned and a new draft program was declared to public. The modification draft program was broadcasted on "mufredat.meb.gov.tr" website for one month with the aim to gather opinion and implications from public and educators. In this new program, the weekly physics course hours at $9^{\text {th }}$ and $10^{\text {th }}$ classes were 2 hours, and 4 hours at $11^{\text {th }}$ and $12^{\text {th }}$ classes. 
Table 11. 2017-Secondary Grade Physics Program Draft

\begin{tabular}{lllll}
\hline 9. Class & Introduction to Physics & Force and Motion & Heat and Temperature & \\
& Matter and Characteristics & Energy & Electrostatic & Optic \\
10.Class & Electric and Magnetism & Pressure and Lifting Force & Waves & \\
11.Class & Force and Motion & Electric and Magnetism & & \\
& Circular Motions & Waves Mechanic & Atom Physics and Nuclear Physics \\
12.Class & Basic Harmonic Motions & $\begin{array}{l}\text { Introduction to Modern } \\
\text { Physics }\end{array}$ & $\begin{array}{l}\text { Modern Physics and Tech. } \\
\text { Practices }\end{array}$ \\
\hline
\end{tabular}

In preparing the 2017 Physics program, the intensity of mathematical operations at the $9^{\text {th }}$ and $10^{\text {th }}$ classes have been kept in minimum level, and it has been aimed to associate the course with daily life. However, at the $11^{\text {th }}$ and $12^{\text {th }}$ classes, the topics have been dealt in a more comprehensive and sophisticated perspective. Thus, it is thought that necessary background would be provided (NEM, 2016).

\section{Conclusion and Discussion}

Program development is a process which can be said to include the stages of determination of goals, preparation of the teaching programs considering the goals, the trial (practice) of the program, the assessment of the program and the improvement of the program (Ertürk, 1984). Teaching program is a guide, namely the plan of a project, which shows what, why and how a subject will be taught during the learning-teaching process (Özçelik, 1987). In this sense, the current study examined the secondary grade Physics programs in Turkey.

The education years of high schools were 3 years in duration between 1923 and 1952. Between 1952-1955, this was increased to 4 years, and in 1956 it was decreased to 3 years again. This 3-year high school education term lasted until 2005 in which it has been increased to 4 years again. It is revealed that between the years of 1924 and 2017, there have been made change studies on physics program 16 times. The total weekly physics course hour at high school was 6 hours in 1924-1931; it was 7 hours in 1931-1934; it was 6 hours in 1934-1937; 9 hours in 1937-1957; and it has been 10 hours since 1957 to today. These course hours have been determined considering the science branches.

The physics programs applied before the one implemented in 2007, were generally similar to each other except the 1974-Modern Science and Mathematics Program and 1922-The Credit System. 1922-The Credit System Program was one of the first right steps in program developing efforts since it was attempted at specific high schools before implementing the new program. However, this system was abolished since the students were out of school and dealt with inappropriate things such as game arcades and unsafe settings when they had no class. All physics programs before the one which was began in 2007 were in the form of spiral in which each class included all physics topics, and this program was different from others in that the topics were given in conceptual level. In the draft Physics program in 2007, the mathematical operations were quite low in the $9^{\text {th }}$ and $10^{\text {th }}$ classes, which indicated a contrast with the exam system then. Thus, it seems that teachers have to distract from the program and tend to do more mathematical operations at $9^{\text {th }}$ and $10^{\text {th }}$ classes with the aim of preparing their students for higher education exams.

Another point regarding the issue was that the physics program was very intense compared to other science courses, and the weekly course hour was the same as others and not enough for such an intense program. As the topics are too many than other science courses, physics teachers have difficulty in completing the topics, which can be solved through increasing the physics course hours.

In a general view of the physics programs since foundation of republic, every program was developed, tried on sample schools and then implemented, which is in accordance with the principals of program development. Still, although the new programs were attempted for one or two years, the necessary modifications or revisions were neglected and implemented to the schools directly. Then, when the problems became obvious throughout the country, a new program was needed, but since the new program would be attempted, but its missing parts would be neglected again, another need for a new program would emerge. It seems like a vicious cycle. Such a situation collide with the fact that education goals are not short-term that can be implemented quite short times.

Additionally, the current study revealed that the programmer dealing with developing physics program in Turkey, do not do related studies concerning unit analysis, they don't describe facilitative goals and behaviors for physics teachers' to prepare lesson plans, namely, they don't set light to physics teachers in this sense, which is one of the vital missing. 


\section{References}

Arslanoğlu, İ. (2001). Orta Öğretimde Sosyoloji Öğretimi [Sociology Teaching in Secondary Education], Türkiye Sosyal Araştırmalar Dergisi. Journal of Social Research in Turkey, 2, 63-89.

Bozan, M. (2002). "PSSC Fizik Programı İle Günümüz Fizik Programlarının Karşılaştırılması” [Comparison of PSSC Physics Program and Today's Physics Programs, Unpublished master thesis, Balıkesir.

Büyükkaragöz, S., \& Çivi, C. (1998). Genel Öğretim Metotları [General Teaching Methods] (8th Ed.). Öz Eğitim Publication, Konya.

Cicioğlu, H. (1985). Türkiye Cumhuriyetinde Illk ve Orta Öğretim [Primary and Secondary Education in the Republic of Turkey]. Ankara Uni. Publication, Ankara, 133-218.

Demirel, Ö. (2004). Kuramdan Uygulamaya Eğitimde Program Geliştirme [Applying the Theory Program Development in Education], (6th Ed.). Pegem A Publication, Ankara.

Ertürk, S. (1984). Eğitimde Program Geliştirme [Program Development in Education] (5th Ed.). Yelkentepe Publications, Ankara.

Milli Eğitim Bakanlığı Öğretim Programlarını İzleme ve Değerlendirme Sistemi (National Education Ministry) (2016). Retrieved January 04, 2017, from http://mufredat.meb.gov.tr/ProgramDetay.aspx?PID=48

Milli Eğitim Bakanlığı Talim ve Terbiye Kurulu Başkanlığı (National Education Ministry Board of Education and Training Board) (2016), Retrieved September 09, 2016, from http://ogm.meb.gov.tr/belgeler/fizik9.pdf

Milli Eğitim Bakanlığı Talim ve Terbiye Kurulu Başkanlığı (National Education Ministry Board of Education and Training Board) (2016). Retrieved September 09, 2016, from https://www.oabtfizik.com/FileUpload/op744050/File/10.pdf

Milli Eğitim Bakanlığı Talim ve Terbiye Kurulu Başkanlığı (National Education Ministry Board of Education and Training Board) (2016). Retrieved September 09, 2016, from https://www.oabtfizik.com/FileUpload/op744050/File/11.pdf

Milli Eğitim Bakanlığı Talim ve Terbiye Kurulu Başkanlığı (National Education Ministry Board of Education and Training Board) (2016). Retrieved September 09, 2016, from https://www.oabtfizik.com/FileUpload/op744050/File/fizik_12

Milli Eğitim Bakanlığı Tebliğler Dergisi (Journal of National Education Ministry). (1947). Issue: 453, Ankara.

Milli Eğitim Bakanlığı Tebliğler Dergisi (Journal of National Education Ministry). (1949). Issue: 912, Ankara.

Milli Eğitim Bakanlığı Tebliğler Dergisi (Journal of National Education Ministry). (1973). Issue: 1731, Ankara.

Milli Eğitim Bakanlığı Tebliğler Dergisi (Journal of National Education Ministry). (1991). Issue 163, Ankara, p.412-425.

Milli Eğitim Bakanlığı Tebliğler Dergisi (Journal of National Education Ministry). (1992). Issue: 128, Ankara, p.314-325.

Milli Eğitim Bakanlı̆̆ı Tebliğler Dergisi (Journal of National Education Ministry). (1996). Issue: 2455, Ankara.

Milli Eğitim Bakanlığı Tebliğler Dergisi (Journal of National Education Ministry). (1997). Issue: 2470, Ankara.

Milli Eğitim Bakanlığı Tebliğler Dergisi (Journal of National Education Ministry). (2005). Issue: 2573, Ankara, p. 381.

Milli Eğitim Bakanlığı Tebliğler Dergisi (Journal of National Education Ministry). (2013). Issue: 2670, Ankara, p.1737.

Milli Eğitim Bakanlığı Tebliğler Dergisi (Journal of National Education Ministry). (2013). Issue: 2667, Ankara, p.199-217.

Milli Eğitim Bakanlığı Tebliğler Dergisi (Journal of National Education Ministry). (2013). Issue: 2666, Ankara, p.188.

Özçelik, D. A. (1987). Eğitim Programları ve Öğretim [Education Programs and Teaching]. ÖSYM Education Publications, Ankara.

Türkoğlu, A. (1984). Türkiye ve Fransa'da Lise Programlarının Karşılaştırmalı Olarak İncelenmesi [Comparative Study of High School Programs in Turkey and France]. Ankara Uni. Publication, Ankara, 180-217.

Ünal, F., \& Ünal, M. (2010). Türkiye'de Ortaöğretim Programlarının Gelişimi [Development of Secondary Education 
Programs in Turkey], Sosyal Bilimler Araştırmaları Dergisi. Journal of Social Sciences Researches, 1, 110-125.

Varış, F. (1976). Eğitimde Program Geliştirme [Program Development in Education]. Ankara Uni. Education Faculty Publication, Ankara.

Yıldırım, A., Şimşek. (2003). Sosyal Bilimlerde Nitel Araştırma Yöntemleri [Qualitative Research Methods in the Social Sciences], (3rd Ed.). Seçkin Publication, Ankara. 